sort are heard today, except occasionally from Cambridge Nobel Laureates. This type of naive positivism was more or less demolished by the bitter and deadly assault it met from three giants of literature-Lawrence, Eliot and Yeats. The second objection has more substance, but Douglas Bush contributes little to the current debate about the moral implications of imminent biologies.

There are, however, some fine things in the book. It was good to read Robert Burton's description of the human brain, from the Anatomy of Melancholy, a reminder of the simple wisdom that was possible before Descartes confused things : the brain "is a soft, marrowish and white substance, engendered of the purest part of seed and spirits, included by many skins, and seated within the skull or brain-pan, and it is the most noble organ under $\mathrm{h} \in$ aven, the dwelling-house and seat of the soul, the habitation of wisdom, memory, judgment, roason, and in which man is most like unto God". And Bush describes well the hatred of scientific rationalism that fired the early romantics. Blake was able to announce that "Art is the Tree of Life ... Science is the Tree of Death". Blake was particularly incensed by Newton, though perhaps unfairly, for Newton himself treated his own discoveries with a response far from any barren rationalism. Blake's true enemy was perhaps something more elusive than science : witness two more of his maxims-" "Energy is Eternal Delight" and "Sooner murder an infant in his cradle than nurse unacted desires".

Bush is an erudite man and a charming writer, yet his book in sum is unsatisfactory, largely because it ignores the biggest factor in the dealings of science and man's imagination-industry, and the social alienation that came in its wake. The "dark, satanic mills" were a bigger threat even for Blake than any scientific law. Today's crop of artists seem to have little quarrel with science as such: they are ready enough to exploit the fruits of electronies and pharmacology. But to a man they are committed to lifelong guerrilla warfare against the structures of industrial society.

Another, though clearly a linked, aspect of the book is its unremitting stand of extreme literary conservatism. Bush views contemporary poets with hostility and distaste : one feels that artists themselves pose bigger problems for his conception of culture than scientists ever will. Freud he berates with a bizarre intensity - it is an unrecognizable Freud to the one who is a hero of Lionel Trilling's marvellous book The Liberal Imagination. Nicholas Evans

\section{THOUGHTFUL READING}

\section{Before Hansard}

By Horace Maybray King. Pp. viii + I14. (Dent: London, November 1968.) $25 s$.

IF society changes in the next three hundred years at least as fast as it has changed in the past three hundred, much of today's Hansard, oven those solid pieces culled from it by Nature's parliamentary correspondent, will no doubt make as amusing reading in 2268 as the titbits of old parliamentary business which Horace King has collected in his anthology. Horace King, the present speaker of the House of Commons, as a hobby, ferrets among the Rolls of Parliament, diaries of parliamentarians and the Parliament journal of the days before Hansard was part and pareel of Westminster. He does not pretend that the excerpts in Before Hansard reflect anything more than the sidelights and trivia of history; the more important and significant passages have been left for a graver book. Nono the less, the author has managed, with his judiciously selected pieces, to establish in an entertaining and sometimes surprising way his well worn theme that human nature has changed but little in the three hundred years which have revolutionized man's environment.
In a lighthearted way Horace King shows that MPs have always spent much of their time complaining about taxes, the cost of living, a sick balance of payments and lobbying for vested interests. They have always bored each other, made weak puns, spoken out, often in vain, against their own humbug; as did Mr Hume in 1832 who "moved the House to omit from the preamble of a Cholera Precautions Bill the words 'Whereas it hath pleased God Almighty to visit', on the grounds that they were 'cant, humbug and hipocrisy'. His amendment was defeated". They have always shown off their vanity. Although in these sensitive days few do so in such a refreshingly frank manner as one Colonel Birch who in 1689 began his speech with, "I am in a new periwig, and pray let the House look at me before I am heard".

This little book also has its surprises. Who, for example, would have thought that the House of Commons was discussing desalination in 1685 or insecticides in 1781 ? But on June 5, 1685, Dr King tells us that an application was made "for granting a longer time in the use of the invention of making seawater fresh and wholesome" and in 1781 Henry Phillips was secking a patent for his insecticide for which he was finally granted a reward in 1785. And in 1668 , one Dr Chamberlayne was lobbying for an invention, which our latter day circumnavigators would find useful, for always "sailing in a straight line against any wind".

Before Hansard was never meant, of course, to be a serious work of history, but, like a collection of epigrams, it is both enjoyable to read and thought provoking.

\section{J. Tooze}

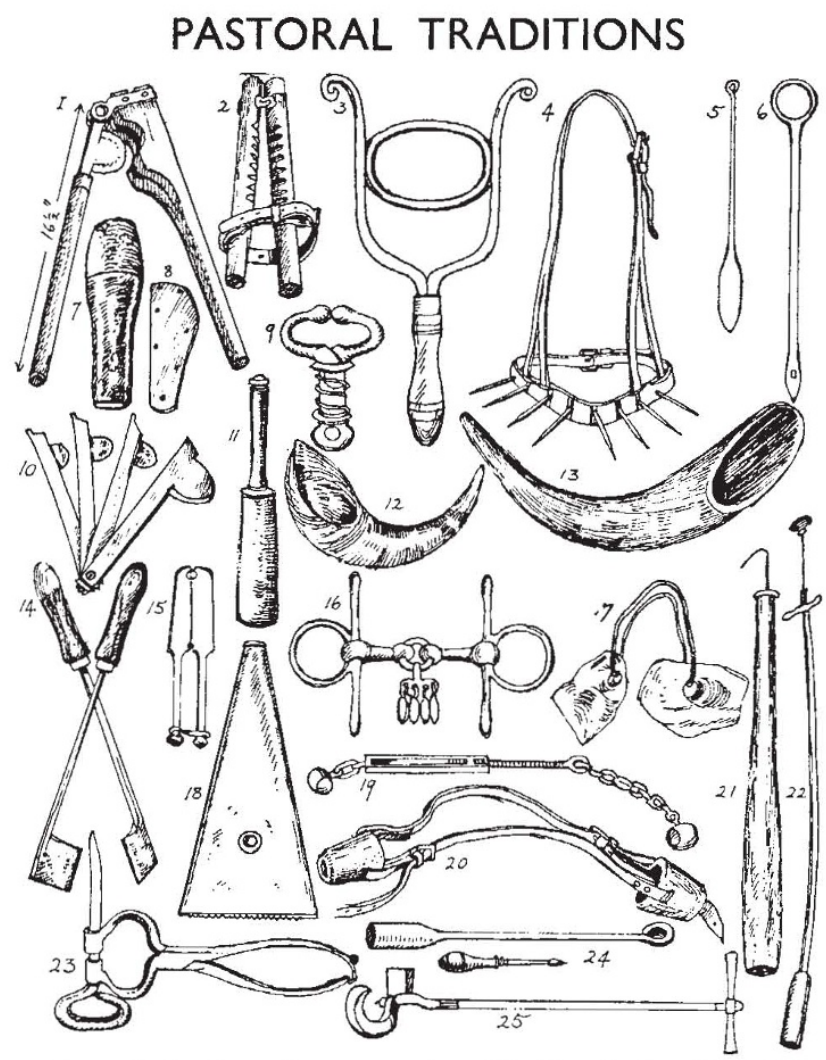

Cow doctors' appliances used until recently in the more remote parts of the Yorkshire Dales. From a chapter, "Cures on the Farm", in Life and Traditions in the Yorkshire Dales, by Marie Hartley and Joan Ingilby (Dent: London, 84s). The authors, who have written several books about this beautiful part of England, have lived in the Dales for many years, and their latest book is a unique record in word and picture of a way of life as it was lived up to the arrival of motor transport, electricity and modern farm machinery. 